\title{
Astilbe Chinensis ethanol extract suppresses inflammation in macrophages via NF-KB pathway
}

\author{
Tae-Young Gil', Bo-Ram Jin', Chul-Hee Hong ${ }^{2}$, Jong Hyuk Park ${ }^{3}$ and Hyo-Jin An ${ }^{1 *}$ (D)
}

\begin{abstract}
Background: Macrophages play a crucial role in inflammation. Astilbe chinensis is one of perennial herbs belonging to the genus Astilbe. Plants in the genus have been used for pain, headaches, arthralgia, and chronic bronchitis. However, the effect of A.chinensis on inflammation remains unclear. To study the anti-inflammatory action of A.chinensis ethanol extract (ACE), we investigated the effect of ACE on the production of pro-inflammatory mediators and cytokines in macrophages.

Methods: We evaluated the effectiveness of ACE in lipopolysaccharide (LPS)-stimulated RAW 264.7 macrophages and thioglycollate (TG)-elicited peritoneal macrophages from male C57BL/6 mice. We measured the levels of proinflammatory mediators and cytokines, and examined the anti-inflammatory actions of ACE on nuclear factor $\mathrm{KB}$ (NF-kB) pathway in the macrophages. Western blot analysis and immunofluorescence microscopy were used to determine protein level and translocation, respectively.
\end{abstract}

Results: ACE suppressed the output of nitric oxide (NO), prostaglandin E2 $\left(\mathrm{PGE}_{2}\right)$, and pro-inflammatory cytokines in stimulated macrophages via inhibiting the expression of inducible nitric oxide synthase (iNOS) and cyclooxygenase2 (COX-2) proteins. ACE suppressed mRNA expression of pro-inflammatory cytokines such as interleukin (IL)- 6 and tumor necrosis factor-alpha (TNF-a). We examined the efficacies of ACE on NF-kB activation by measuring the expressions including $\mid \mathrm{KB}$ kinase (IKK), inhibitor of $\mathrm{KB}(\mathrm{I} \mathrm{KB})$, and nuclear p65 proteins. In addition, the inhibition of NF-kB p65's translocation was determined with immunofluorescence assay.

Conclusion: Our findings manifested that ACE inhibited LPS or TG-induced inflammation by blocking the NF-kB signaling pathway in macrophages. It indicated that ACE is a potential therapeutic mean for inflammation and related diseases.

Keywords: Astilbe chinensis, Macrophages, NF-kB pathway, Inflammation, In vitro, Ex vivo

\section{Background}

The inflammatory affair is a successive and well-modulated mechanism against the various stimulations and initial step in the defense system. Target cells like macrophages can be induced by physical, microbial, chemical, and immune logical reactions producing inflammatory responses [1].

\footnotetext{
*Correspondence: hjan@sj.ac.kr; sangjipharm@gmail.com

'Department of Pharmacology, College of Korean Medicine, Sangji University, 83, Sangjidae-gil, Wonju-si, Gangwon-do 26339, Republic of Korea Full list of author information is available at the end of the article
}

However, prolonged or chronic inflammation causes various chronic diseases including cancers, diabetes mellitus, and metabolic syndromes. Macrophages are crucial in directing the host immune response against infection as well as in many pathophysiological processes associated with inflammation. They are strong secretory cells releasing a set of pro-inflammatory mediators [2]. Nitric oxide (NO), prostaglandin $\mathrm{E}_{2} \quad\left(\mathrm{PGE}_{2}\right)$, tumor necrosis factor-alpha (TNF- $\alpha$ ), and interleukins (ILs) are pro-inflammatory mediators and cytokines which promote inflammatory responses

(c) The Author(s). 2020 Open Access This article is licensed under a Creative Commons Attribution 4.0 International License, which permits use, sharing, adaptation, distribution and reproduction in any medium or format, as long as you give appropriate credit to the original author(s) and the source, provide a link to the Creative Commons licence, and indicate if changes were made. The images or other third party material in this article are included in the article's Creative Commons licence, unless indicated otherwise in a credit line to the material. If material is not included in the article's Creative Commons licence and your intended use is not permitted by statutory regulation or exceeds the permitted use, you will need to obtain permission directly from the copyright holder. To view a copy of this licence, visit http://creativecommons.org/licenses/by/4.0/ The Creative Commons Public Domain Dedication waiver (http://creativecommons.org/publicdomain/zero/1.0/) applies to the data made available in this article, unless otherwise stated in a credit line to the data. 
in macrophages [3]. On this note, the expressive amounts of pro-inflammatory mediators and cytokines are considered as indices of the degree of inflammation.

Lipopolysaccharide (LPS)-induced inflammation in macrophages is widely used in inflammatory studies. LPS is the dominant element of endotoxins derived from Gramnegative bacterial outer membrane [4]. LPS induces inflammatory responses and facilitates the yield of proinflammatory mediators and cytokines which is done by binding to Toll-like receptor 4 (TLR4) [5]. The inflammatory mediators and cytokines can be modulated via the activation of transcription factors, such as nuclear factor- $\mathrm{kB}$ $(\mathrm{NF}-\kappa \mathrm{B})$, mediated by LPS-induced signaling cascade [6]. NF- $\mathrm{kB}$ what is assembled with p65 and p50 subunits which regulate multiple transcriptional factors including inducible enzymes such as inducible nitric oxide synthase (iNOS), cyclooxygenase-2 (COX-2), and pro-inflammatory cytokines [7]. NF- $\mathrm{kB}$ is isolated as an inactive complex bound to inhibitor of $\kappa \mathrm{B}(\mathrm{I} \kappa \mathrm{B})$ in the cytoplasm. The IкB proteins are swiftly phosphorylated in the matter of proinflammatory stimuli and they are eventually degraded via the proteosomal pathway which is involved in the formation of IKB kinase (IKK) complexes [8].

Astilbe chinensis (A.chinensis) (Maxim.) Franch. \& Sav. (ID: kew-2,656,728) belongs to the family Saxifragaceae, and usually grows in moist fields and mountains [9]. Plants in the genus Astilbe, including A.chinensis, have been known to nurse chronic bronchitis, arthralgia, inflammation, pain, and headache. The dried roots of A.chinensis and its chemical constituents have been used not only as antipyretic and analgesic remedies but also for the treatment of bronchitis [10]. In addition, there are studies on various effects such as the anti-obesity [11], platelet modulating [12], and $\alpha$-glucosidase inhibitory activities of A.chinensis [13]. There are bioactive compounds from A.chinensis, such as astilbic acid, astilbin, and bergenin (Table 1). The anti-inflammatory activity of astilbic acid has been shown in bone marrow-derived mast cells [17] and in allergic asthma [14]. Because inflammation is deeply involved in innate immunity, this study would figure out the effect in the other immune cells. However, the efficacies of ACE on inflammation have not been investigated in macrophages. Hence, this study would investigate the anti-inflammatory effectiveness of ACE in murine RAW 264.7 and primary peritoneal macrophages from male C57BL/6 mice. Since we would like to study the effect of ACE as much as possible related to human biology, we applied it on peritoneal macrophages, the most often used as a model system in macrophages-related functional studies.

\section{Methods}

\section{Chemicals and reagents}

Dulbecco's modified Eagle's medium (DMEM), fetal bovine serum (FBS), penicillin, and streptomycin were got from Life Technologies Inc. (Grand Island, NY, USA). LPS (Escherichia coli, serotype 055:B5), 3-(4,5-dimethylthiazol2-yl)-2,5-diphenyltetrazolium bromide (MTT), N6-(1-Iminoethyl) lysine (NIL), NS-398, and Griess reagent were bought from Sigma Chemical Co. (St. Louis, MO, USA). Dimethyl sulfoxide (DMSO) was purchased from Junsei Chemical Co. Ltd. (Tokyo, Japan). Primary antibodies including iNOS, COX-2, NF-кB p65, p-IкB- $\alpha$, IкB- $\alpha$, and $\beta-$ actin monocolonal antibodies were bought from Santa Cruz Biotechnology (Santa Cruz, CA, USA). p-IKK- $\alpha / \beta$, IKK- $\alpha / \beta$, and PARP antibodies were got from Cell Signaling Technology (Danvers, MA, USA). Horseradish peroxidase-conjugated secondary antibodies and normal goat serum were got from Jackson Immuno Research laboratories, Inc. (West Grove, PA, USA). SYBR green master mix was obtained from Applied Biosystem (Foster, CA, USA). IL-6, TNF- $\alpha$, and glyceraldehyde-3-phosphate dehydrogenase (GAPDH) oligonucleotide primers were got from Bioneer (Daejeon, Republic of Korea). The enzymelinked immunosorbent assay (ELISA) kits for IL-6, TNF- $\alpha$, and $\mathrm{PGE}_{2}$ were obtained from $\mathrm{R} \& \mathrm{D}$ Systems (Minneapolis, MN, USA). Mounting medium with 4,6-diamidino-2phenylindole (DAPI) was got from Vector Laboratories, Inc. (CA,USA). Alexa Flour 488 goat anti-rabbit IgG H\&L was obtained from Invitrogen Corp (Carlsbad, CA, USA).

\section{Preparation of ethanol extract of Astilbe chinensis (ACE)}

ACE was a gift from Institute of Natural Cosmetic Industry for Namwon (Namwon, Jeollabuk-do, Republic of Korea). The dried and powdered rhizome of plant material was extracted thrice by maceration with $95 \%$ ethanol. The extract was evaporated in vacuo at $40{ }^{\circ} \mathrm{C}$, was filtered, and freeze-dried in vaccum. The freeze-dried sample was dissolved in DMSO at a final concentration of $50 \mathrm{mg} / \mathrm{mL}$ for the bio assays.

\section{Cell culture and sample treatment}

The RAW 264.7 macrophages cell line was purchased from Korea Cell Line Bank (KCLB, Seoul, Republic of

Table 1 Active compound of Astilbe chinensis

\begin{tabular}{lll}
\hline Active compound & PubChem CID & Reference \\
\hline Astilbic acid & $12,016,586$ & (Yuk, Lee, Kwon, Cai, Jang, Oh, Lee and Ahn 2011 [14]) \\
Astilbin & 119,258 & (Chen et al. 2018 [15]) \\
Bergenin & 66,065 & (Chen and Nie 1988 [16]) \\
\hline
\end{tabular}


Korea). This cell line was cultured in DMEM supplemented with $10 \% \mathrm{FBS}$, penicillin $(100 \mathrm{U} / \mathrm{mL})$, and $1 \%$ streptomycin $(100 \mu \mathrm{g} / \mathrm{mL})$ in $37^{\circ} \mathrm{C}$ and $5 \% \mathrm{CO}_{2}$ incubator. ACE was dissolved in DMSO and the cells were treated with $12.5,25$, or $50 \mu \mathrm{g} / \mathrm{mL}$ ACE. The cells $(1 \times$ $10^{5}$ cells $/ \mathrm{mL}$ ) were stimulated with $1 \mu \mathrm{g} / \mathrm{mL}$ of LPS for the indicated time prior to treatment with ACE for $1 \mathrm{~h}$.

\section{Experimental animals and sample treatment}

Male C57BL/6 mice ( $n=4 ; 8$ weeks old) were got from Daehan Biolink Co. (Daejeon, Republic of Korea). All animals were housed in accordance with the guidelines for the care and use of laboratory animals. The guidelines were adopted and promulgated by Sangji University according to the requirements demonstrated by the National Institutes of Health. All the experimental protocols were approved based on the Institutional Animal Care and Use Committee (IACUC) of Sangji University before the beginning of the study (IACUC Animal approval protocol No.2018-3). The mice were housed in a cage and fed standard laboratory chow in the animal room with $12 \mathrm{~h}$ dark/light cycles and constant condition; $20 \pm 5{ }^{\circ} \mathrm{C}$ temperature, $40-60 \%$ humidity) for a week. We got the primary peritoneal cells from the mice using the protocol described formerly $[18,19]$. We used $4 \%$ brewer thioglycollate (TG, Difco, Laboratories, Detroit, MI, USA) to isolate the peritoneal macrophages under the inflammation. Each mouse was intraperitoneally administered $3 \mathrm{~mL}$ of $4 \%$ TG for 4 days. Prior collection of the peritoneal primary macrophages from the mice, we sacrificed them in accordance with the IACUC animal approval. Every effort was made to minimize animal suffering. Animals were fasted for $12 \mathrm{~h}$ and euthanized by cervical dislocation. To harvest the primary cells from mice, we performed peritoneal lavage with $8 \mathrm{ml}$ of Hank's balanced salt solution (HBSS, Gibco BRL, Grand Island, NY, USA) containing $10 \mathrm{U} / \mathrm{mL}$ heparin. The cells were distributed in DMEM in 24-well tissue culture plates $\left(3 \times 10^{5}\right.$ cells/well $)$ and were incubated for $3 \mathrm{~h}$ at $37^{\circ} \mathrm{C}$ under an atmosphere of $5 \%$ $\mathrm{CO}_{2}$. They were washed three times with HBSS to remove non-adherent cells, and equilibrated with DMEM supplemented with $10 \%$ FBS before sample treatment. ACE was dissolved in DMSO and the cells were treated with 12.5, 25 , or $50 \mu \mathrm{g} / \mathrm{mL}$ ACE. The cells were stimulated with 20 $\mathrm{U} / \mathrm{mL}$ IFN- $\gamma$ (BD Pharmingen ${ }^{\mathrm{Tw}}$, BD Biosciences, USA) for $6 \mathrm{~h}$, and with $1 \mu \mathrm{g} / \mathrm{mL}$ of LPS for the indicated time prior to treatment with ACE for $1 \mathrm{~h}$.

\section{NO production assay}

NO content was measured indirectly by assaying the culture supernatant for nitrite with Griess reagent (1\% sulfanilamide in $5 \%$ phosphoric acid, $1 \% \alpha$-naphthylamide in $\mathrm{H}_{2} \mathrm{O}$ ). NO production from the macrophages was in form of $\mathrm{NO}_{2}$ in the culture medium. The cells were distributed in DMEM IN 24-well culture plates $\left(1 \times 10^{5}\right.$ cells $\left./ \mathrm{mL}\right)$ and were incubated for $48 \mathrm{~h}$. Cell culture media $(50 \mu \mathrm{L})$ was mixed with $50 \mu \mathrm{L}$ of Griess reagent in a 96-well plate and incubated at room temperature for $15 \mathrm{~min}$ followed by the measurement of the absorbance at $540 \mathrm{~nm}$ using an automatic microplate reader (Titertek Multiskan). Values are presented as mean \pm S.D. of three independent experiments.

\section{$\mathrm{PGE}_{2}$ assay}

The macrophages $\left(1 \times 10^{5}\right.$ cells $\left./ \mathrm{mL}\right)$ were treated with ACE for $1 \mathrm{~h}$ prior to stimulation with LPS $(1 \mu \mathrm{g} / \mathrm{mL})$. After $24 \mathrm{~h}$, the level of $\mathrm{PGE}_{2}$ in the culture media was measured using $\mathrm{PGE}_{2}$ enzyme immune assay kit (R\&D Systems, Minneapolis, MN, USA). The experiments were performed in triplicate. Values are presented as mean \pm S.D. of three independent experiments.

\section{Cytokine assays}

RAW 264.7 macrophages $\left(1 \times 10^{5}\right.$ cells $\left./ \mathrm{mL}\right)$ were pretreated with ACE for $1 \mathrm{~h}$ prior to the addition of LPS. The culture media were collected about $24 \mathrm{~h}$ posttreatment with $\mathrm{ACE}$ and stored at $-80{ }^{\circ} \mathrm{C}$. The levels of IL- 6 and TNF- $\alpha$ were measured with EIA kits according to the manufacturer's instructions. Values are presented as mean \pm S.D. of three independent experiments.

\section{Quantitative real-time PCR analysis (qRT-PCR)}

RAW 264.7 macrophages $\left(1 \times 10^{5}\right.$ cells $\left./ \mathrm{mL}\right)$ were homogenized, and total RNA was isolated using an easyBLUE $^{\mathrm{ma}}$ total RNA extraction kit (iNtRON Biotechnology Inc., Gyeonggi-do, South Korea). cDNA was obtained using isolated total RNA $(1 \mu \mathrm{g}), \mathrm{d}(\mathrm{T}) 16$ primer, and avian myeloblastosis virus reverse transcriptase (AMVRT). Relative gene expression was quantified with realtime PCR (Real Time PCR System 7500, Applied Biosystems, CA, USA) with SYBR green PCR mast mix (Applied Biosystems, CA, USA). The gene Ct values of IL-6 and TNF- $\alpha$ were normalized with the gene express 2.0 program (Applied Biosystems, CA, USA) to the Ct values of GAPDH. Values are presented as mean \pm S.D. of three independent experiments.

\section{Nuclear extraction}

RAW264.7 macrophages were plated in $60-\mathrm{mm}$ dishes $\left(1 \times 10^{5}\right.$ cells $\left./ \mathrm{mL}\right)$ and pre-treated with ACE for $1 \mathrm{~h}$ prior to the addition of LPS. After $30 \mathrm{~min}$, the cells washed three times with PBS, scraped into $1 \mathrm{~mL}$ of cold PBS, and pelleted by centrifugation. Cell pellets were resuspended in hypotonic buffer (10 mM HEPES, pH 7.9, 1.5 $\mathrm{mM} \mathrm{MgCl}_{2}, 10 \mathrm{mM} \mathrm{KCl}, 0.2 \mathrm{mM}$ PMSF, $0.5 \mathrm{mM}$ DTT, $10 \mu \mathrm{g} / \mathrm{mL}$ aprotinin). Then, cells incubated on ice for 15 min. Next, cells were lysed by adding $0.1 \%$ Nonidet P- 40 and vortexed vigorously for $30 \mathrm{~min}$. Nuclei were pelleted 
by centrifugation at $12,000 \times \mathrm{g}$ for $2 \mathrm{~min}$ at $4{ }^{\circ} \mathrm{C}$ and resuspended in high salt buffer (20 mM HEPES, pH 7.9, $25 \%$ glycerol, $400 \mathrm{mM} \mathrm{KCl}, 1.5 \mathrm{mM} \mathrm{MgCl}_{2}, 0.2 \mathrm{mM}$ EDTA, $0.5 \mathrm{mM}$ DTT, $1 \mathrm{mM} \mathrm{NaF,} 1 \mathrm{mM}$ sodium orthovandate).

\section{Western blot analysis}

Protein extracts were isolated from the cell lines $\left(1 \times 10^{5}\right.$ cells $/ \mathrm{mL}$ ) using the protein lysis buffer Pro-prep ${ }^{\text {tw }}$ (Intron biotechnology Inc., Gyeonggi-do, South Korea). Protein samples were separated on an $8-12 \%$ sodium dodecyl sulphate-polyacryl-amide gel. After electrophoresis, proteins were transferred to polyvinylidenedifluoride membranes. The membranes were blocked with $2.5-5 \%$ skim milk for $30 \mathrm{~min}$ and incubated overnight with specific primary antibodies in Tris-buffered saline (TBS) containing $0.1 \%$ Tween 20 at $4{ }^{\circ} \mathrm{C}$. Primary antibody was removed by washing the membrane three times in TBS-T buffer, and incubated for $2 \mathrm{~h}$ with horseradish peroxidase-conjugated secondary antibody (1:2500) at $25^{\circ} \mathrm{C}$. After washing thrice in TBS-T, immuno-detection bands were reacted with ECL solution (Absignal, Seoul, Republic of Korea) and captured on X-ray film (Agfa, Belgium). Values are presented as mean \pm S.D. of three independent experiments.

\section{Immunofluorescence assay}

Cells $\left(1 \times 10^{5}\right.$ cells $\left./ \mathrm{mL}\right)$ were cultured directly on the camber slide (Lab-Tek II chamber slide \#154526, 4 well) for $24 \mathrm{~h}$ to detect NF-kB/p65 localization. After stimulation with LPS in the presence or absence of ACE, the cells were fixed with $100 \%$ methanol for $30 \mathrm{~min}$ at room temperature and blocked with $10 \%$ normal goat serum. The cells were incubated overnight with specific primary antibodies in $10 \%$ blocking solution. After washing the primary antibodies with $0.3 \%$ Triton $\mathrm{X}$ in PBS for 30 min, Alexa fluor 488 goat anti-rabbit IgG was applied for $1 \mathrm{~h}$. Cells were mounted with mounting medium containing 4', 6-diamidino-2-phenylindole (DAPI) and observed under a fluorescence microscope.

\section{Statistical analysis}

Results are expressed as the mean \pm S.D. of triplicate experiments. Statistically significant differences were determined using ANOVA and Dunnett's post hoc test, and $p$-values $>0.05$ indicated statistical significance.

\section{Results}

\section{Effects of ACE on the production of inflammatory mediators in RAW 264.7 macrophages}

$\mathrm{NO}$ is a major mediator in the inflammatory system [20] and hence, controlling its production has an important meaning in the investigation on an anti-inflammation. The level of NO was figured out with Griess reaction test. Whereby, the nitrite ion in the sample was measured by comparing its absorbance with the prepared standard [20]. We confirmed the inhibitory effectiveness of ACE on NO production in murine macrophage cell line $\left(1 \times 10^{5}\right.$ cells $\left./ \mathrm{mL}\right)$ (Fig. 1a). There was about fourfold increase in NO production in LPS-stimulated group compared to the control group. However, ACE suppressed NO production in a dose-dependent manner in the cells. The inhibitory action of $25 \mu \mathrm{g} / \mathrm{mL}$ ACE on NO production was similar to that of the positive control, NIL $(20 \mu \mathrm{M})$. When macrophages are exposed to LPS, the expression of iNOS ultimately results in the overproduction of NO [21]. iNOS is an NO synthase, which indicates that the suppression of iNOS expression directly correlates with $\mathrm{NO}$ production in inflammatory responses [22]. We examined the level of expression of iNOS protein in RAW 264.7 macrophages $\left(1 \times 10^{5}\right.$ cells/ $\mathrm{mL}$ ) with western blot assay to determine if the previous inhibitory effect was connected to the modulation of the expression of iNOS. Compared to the control group, LPS $(1 \mu \mathrm{g} / \mathrm{mL})$ caused an increase in the expression of iNOS protein. Pre-treatment with ACE $(50 \mu \mathrm{g} / \mathrm{mL})$ reduced the expression of iNOS significantly (Fig. 1b).

$\mathrm{PGE}_{2}$ is commonly considered a pro-inflammatory signaling molecule [23] and thus, we examined its output in murine RAW 264.7 cell line $\left(1 \times 10^{5}\right.$ cells $\left./ \mathrm{mL}\right)$ (Fig. 1 c). The cellular exposure to LPS remarkably stimulated the yield of $\mathrm{PGE}_{2}$ compared with control group. However, treatment with $\mathrm{ACE}$ inhibited the making of $\mathrm{PGE}_{2}$ in a dose-dependent manner in macrophages. The highest concentration of ACE $(50 \mu \mathrm{g} / \mathrm{mL})$ showed a significant downregulation on $\mathrm{PGE}_{2}$ production. COX-2, one of the inducible enzymes associated with excessive production of $\mathrm{PGE}_{2}$, acts as pro-inflammatory mediators in inflammatory state [24]. Hence, we assessed the effectiveness of ACE on the expression of COX-2 protein in RAW 264.7 macrophages $\left(1 \times 10^{5}\right.$ cells $\left./ \mathrm{mL}\right)$ with western blot assay (Fig. $\left.1 \mathrm{~d}\right)$. The LPS-stimulated group showed higher expression of COX-2 protein than the LPS-untreated group. However, the expressive level of COX-2 protein was down-regulated in a dose-dependent manner by ACE. Pre-treatment of RAW 264.7 macrophages with 25 and $50 \mu \mathrm{g} / \mathrm{mL}$ ACE showed significant suppression.

\section{Effects of ACE on LPS-induced pro-inflammatory cytokines in RAW264.7 macrophages}

Cytokines are crucial local protein mediators got involved in various biological processes for instance cell growth and activation, inflammation, immunity, and differentiation. They have pivotal role in autoimmune diseases [25]. Pro-inflammatory cytokines participate in the prolonging of chronic inflammation [20]. Therefore, the regulation of these cytokines could be a budding strategy in the control of inflammation or related diseases. To 
A

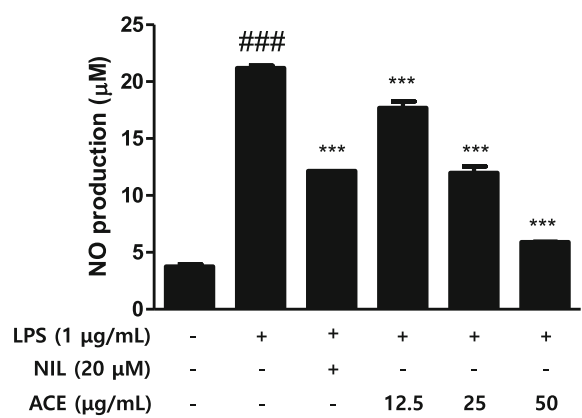

B
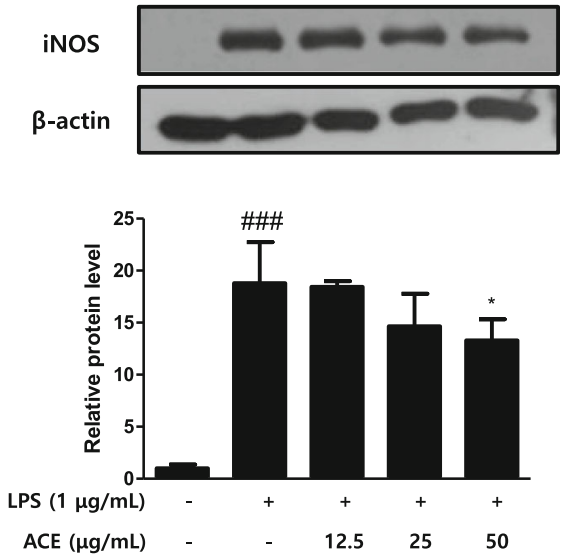

D
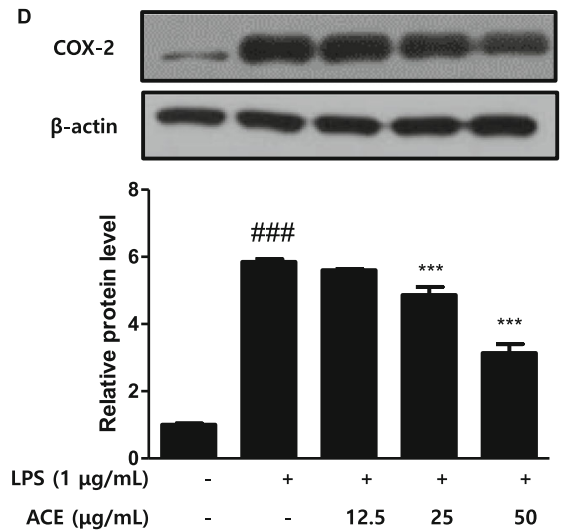

Fig. 1 Effects of ACE on the levels of inflammatory mediators in RAW 264.7 macrophages. Cells were treated with 12.5, 25, or $50 \mu \mathrm{g} / \mathrm{mL}$ of ACE for $1 \mathrm{~h}$ prior to the addition of LPS $(1 \mathrm{\mu g} / \mathrm{mL})$, and the cells were incubated for $24 \mathrm{~h}$ and $48 \mathrm{~h}$, respectively. a NO and (c) PGE 2 level were figured out with Griess reagent and the EIA kit, respectively. NIL $(20 \mu \mathrm{M})$ or NS398 $(5 \mu \mathrm{M})$ was used as positive control. The protein level of (b) iNOS and (d) COX-2 were determined by western blot analysis with specific antibodies. Densitometric analysis was performed with Image J software (version 1.50i). Values are presented as mean \pm S.D. of three independent experiments. ${ }^{\# \# \# ~} p<0.001$ when compared with control; ${ }^{*} p<0.05,{ }^{* * * *} p<0.001$ when compared with LPS-induced group. Significant differences among treated groups were determined by ANOVA and Dunnett's post hoc test

investigate the effect of $\mathrm{ACE}$ on the yield of proinflammatory cytokines for example TNF- $\alpha$ and IL- 6 in LPS-stimulated macrophages $\left(1 \times 10^{5}\right.$ cells $\left./ \mathrm{mL}\right)$, we carried out qRT-PCR to measure the mRNA expression of the cytokines (Fig. 2a), and ELISA for cytokine production (Fig. 2b). With regards to mRNA expression, the cell pre-treated with ACE showed attenuated expression level in a dose-dependent manner even though the group with the lowest concentration of ACE $(12.5 \mu \mathrm{g} /$ $\mathrm{mL}$ ) had a higher mRNA expression of the cytokines than the untreated LPS-induced group (Fig. 2a). Furthermore, TNF- $\alpha$ and IL- 6 production levels in the LPSstimulated group markedly increased comparing the control group. Yet, treatment with 12.5, 25, and $50 \mu \mathrm{g} /$ $\mathrm{mL}$ of ACE markedly diminished the production of cytokines (Fig. 2b).

\section{Effects of ACE on LPS-induced NF-KB pathway in RAW 264.7 macrophages}

As controlling the transcription of various genes, NF- $\mathrm{kB}$ has an pivotal role in the development of acute and chronic inflammatory diseases [26]. We evaluated the effectiveness of ACE on NF- $\mathrm{kB}$ activation in macrophages $\left(1 \times 10^{5}\right.$ cells $\left./ \mathrm{mL}\right)$ through measurement the protein expression and translocation of NF- $\mathrm{kB}$ p65 (Fig. 3). As shown in the figures, NF- $\mathrm{kB}$ p 65 translocation to the nucleus was inhibited by ACE in a dose-dependent manner. Western blot assay with cytosolic and nuclear fractions expressed increased amount of NF-kB p65 in the nucleus of the LPS-stimulated group for $30 \mathrm{~min}$ (Fig. 3a). As shown in Fig. 3d, the inhibitory action of ACE on translocation of NF- $\mathrm{KB}$ p65 was assessed in each group. 

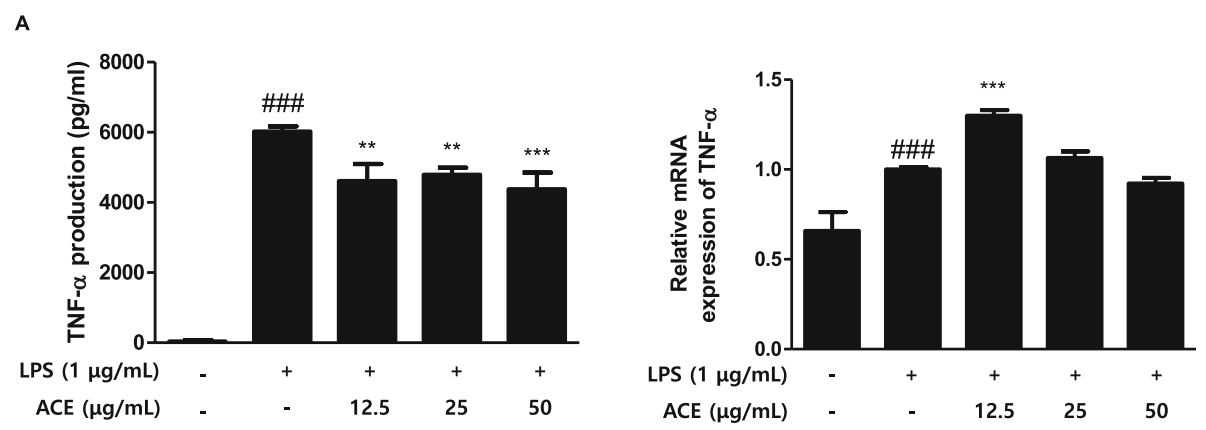

B
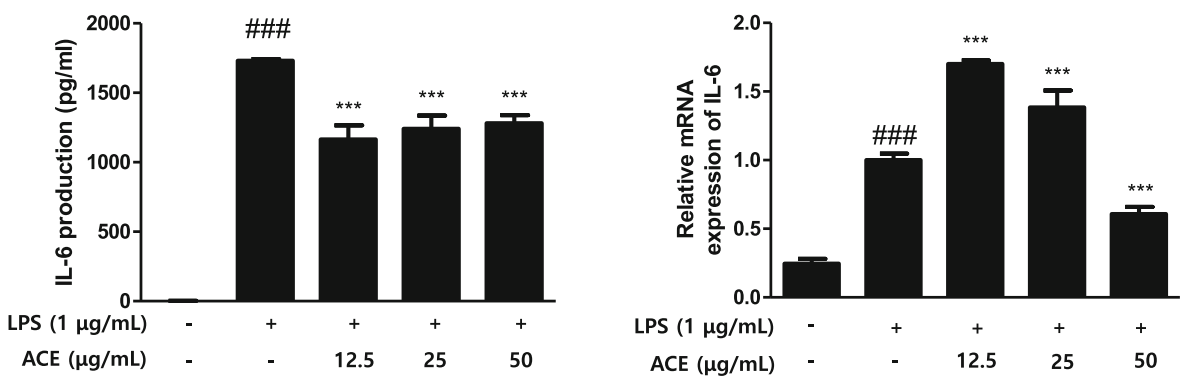

Fig. 2 Effects of ACE on LPS-induced pro-inflammatory cytokines in RAW 264.7 macrophages. Cells were treated with 12.5, 25, or 50 $\mu \mathrm{g} / \mathrm{mL}$ of ACE for $1 \mathrm{~h}$ prior to the addition of LPS $(1 \mu \mathrm{g} / \mathrm{mL})$. The cells were further incubated for $24 \mathrm{~h}$, and cytokine production was measured with EIA kits. After $6 \mathrm{~h}$ of incubation with LPS, mRNA expression of TNF- $a$ and IL- 6 were determined with quantitative real-time PCR. The data shown represent mean \pm S.D. of three independent experiments. ${ }^{\# \# \#} p<0.001$ when compared with control; ${ }^{* *} p<0.01,{ }^{* * *} p<0.001$ when compared with LPSstimulated group. Significant differences between treated groups were determined by ANOVA and Dunnett's post hoc test

$\mathrm{NF}-\mathrm{kB}$ is segregated in the cytoplasm which is done by binding to inhibitory proteins like IKBs [27], and thus, we experimented on the phosphorylation of IkB in LPSstimulated RAW 264.7 macrophages. As shown in Fig. $3 \mathrm{~b}, \mathrm{ACE}$ markedly suppressed IкB $\alpha$ phosphorylation in a dose dependent manner and restored I $\mathrm{K} \mathrm{B} \alpha$ degradation.

The IKK complex incorporates two catalytic subunits, $\mathrm{IKK} \alpha$ and IKK $\beta$. It regulates the activation of NF- $\mathrm{KB}$ transcription factors, which plays a crucial activity in inflammation [28]. Figure 3c showed the protein expression of $I K K \alpha / \beta$ in the groups. Only LPS-stimulated group showed activated IKK comparing to the control group. At 12.5, 25, and $50 \mu \mathrm{g} / \mathrm{mL}$, ACE blocked the activation of IKK significantly.

\section{Effects of AxCE on LPS-induced production of inflammatory mediators in peritoneal macrophages}

As crucial cellular effectors to nonspecific host defense, macrophages emit different inflammatory mediators in the immune system [2]. Primary peritoneal macrophages were isolated from the mice under TG treatment. It took 3 days to isolate the stimulated primary cells after which they were incubated for $24 \mathrm{~h}$ for stabilization. After the pre-treatment with ACE and positive control for $1 \mathrm{~h}$, the cells were exposed to rIFNy and LPS for $6 \mathrm{~h}$ and $48 \mathrm{~h}$, respectively, to induce inflammatory responses. We confirmed the suppressive effects of $\mathrm{ACE}$ on $\mathrm{NO}$ and $\mathrm{PGE}_{2}$ production in peritoneal macrophages $\left(3 \times 10^{5}\right.$ cells $\left./ \mathrm{mL}\right)$ (Fig. 4). As shown in Fig. 4a, NO production was increased by about four folds in rIFNy- and LPS-stimulated groups comparing to the control group. However, the production was down-regulated by ACE in a dose-dependent manner. The groups treated with 25 and $50 \mu \mathrm{g} / \mathrm{mL}$ of ACE showed similar levels of production to the positive control group, NIL $(20 \mu \mathrm{M})$. In Fig. $4 \mathrm{~b}$, the level of $\mathrm{PGE}_{2}$ increased significantly in rIFN $\gamma$ - and LPS-stimulated groups against the control group. The production level of the positive control, NS398 $(5 \mu \mathrm{M})$, in the stimulated groups was the same as that in the non-stimulated group. In addition, the highest concentration of ACE $(50 \mu \mathrm{g} / \mathrm{mL})$ showed a significant inhibition of $\mathrm{PGE}_{2}$ production.

\section{Discussion}

Inflammation is a host protective response against numerous alien pathogens or tissue injury. It occurs in organisms not only to remove harmful stimuli but also to evoke the curing and repairing affairs for damaged tissues $[29,30]$. However, prolonged inflammation causes 


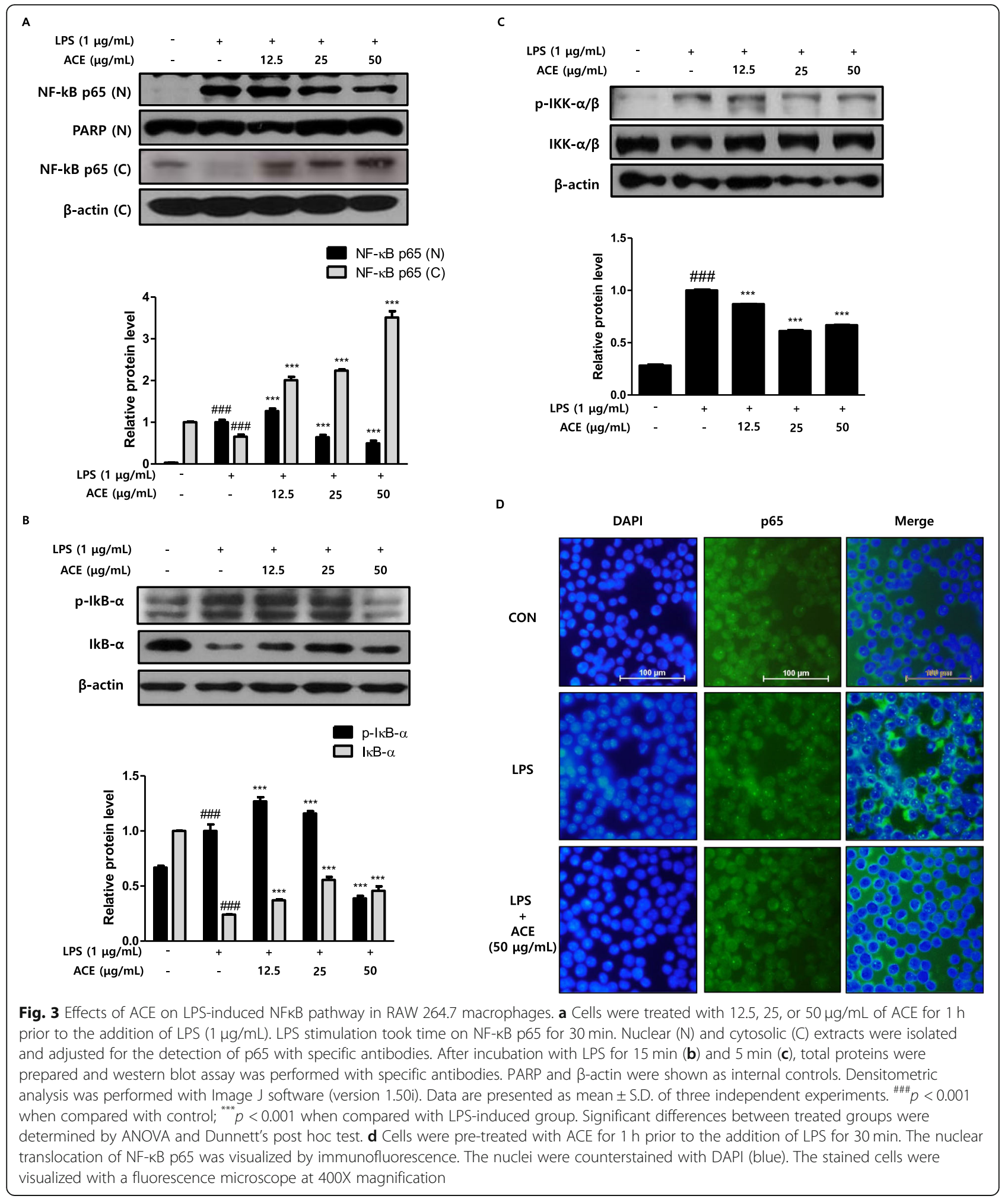

health problems [31]. Hence, this study examined the innate immune system as related to inflammation.

In traditional medicine, A.chinensis is known for its anti-inflammatory, anti-cancer, anti-obesity and hepato- protective effects $[11,13]$. Foregoing studies showed the anti-inflammatory efficacy of astilbic acid from A.chinensis on mast cells [17], and its protective effect on Ultraviolet B-injured keratinocytes [9] suggesting possibility 


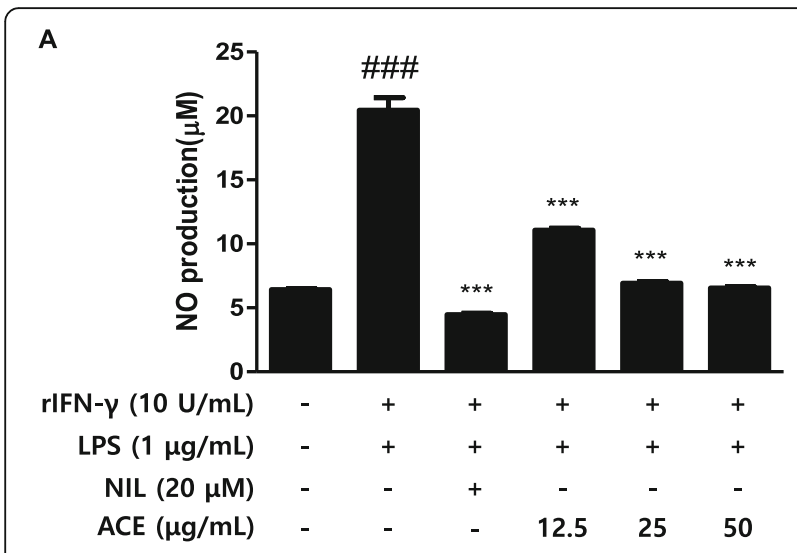

B

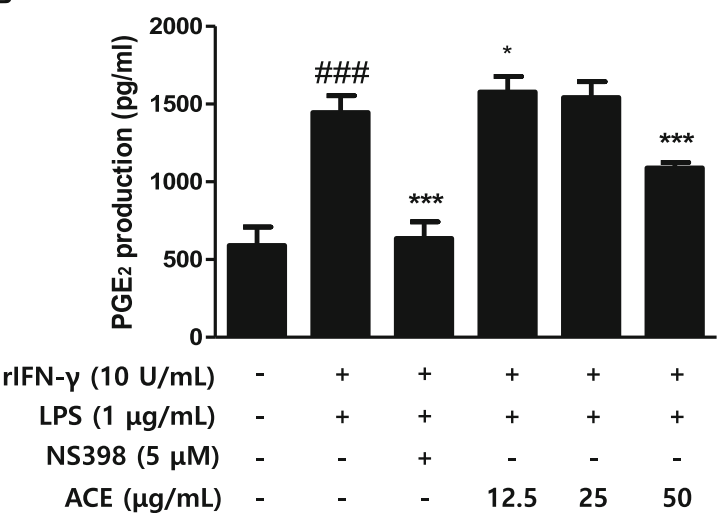

Fig. 4 Effects of ACE production of inflammatory mediators in stimulated primary peritoneal macrophages. Thioglycollate (3\%), rlFN- $\gamma$ $(10 \mathrm{U} / \mathrm{mL})$, and LPS $(1 \mu \mathrm{g} / \mathrm{mL})$-stimulated primary peritoneal macrophages were incubated for $48 \mathrm{~h}$. a $\mathrm{NO}$ and (b) $\mathrm{PGE}_{2}$ level were measured with Griess reagent and the EIA kit, respectively. NIL (20 $\mu \mathrm{M})$ or NS398 (5 $\mu \mathrm{M})$ was used as positive control. Values are presented as mean \pm S.D. of three independent experiments. ${ }^{\# \# \# ~} p<0.001$ when compared with control; ${ }^{*} p<0.05,{ }^{* * *} p<0.001$ when compared with LPS-induced group. Significant differences between treated groups were determined by ANOVA and Dunnett's post hoc test

as anti-inflammatory means. Also, there are other constituents for the effects including astilbin for LPS-induced macrophages [32] and bergenin for synovial inflammation [33]. In this context of the effective elements, we assumed there is synergistically anti-inflammatory effect. Therefore, we figured out the efficacies of ACE on LPS or TG-treated macrophages.

Macrophages are the primary cells in the immune system which originated as blood monocytes [3]. They are important cellular effectors in nonspecific host defense, producing an array of inflammatory mediators, bioactive lipids, and hydrolytic enzymes which are involved in tissue injury [2]. In the present study, the levels of inflammatory mediators such as $\mathrm{NO}$ and $\mathrm{PGE}_{2}$ were determined in murine RAW 264.7 macrophages and primary peritoneal macrophages. Macrophages in the peritoneum under nonelicited state are usually not enough for experimental studies. Sterile eliciting agents such as Brewer's TG broth or proteose peptone can be used in the peritoneal cavity to rise the yield of macrophages [34]. Either cell line or peritoneal macrophage was stimulated with LPS, which is a strong activator of TLR4 signal. LPS triggers the most influential microbial initiator in the inflammatory responses for instance septic shock, microbial violation, or fever [35]. LPS evokes inflammatory responses and binding complex in macrophages through Toll-like family receptors and the co-receptor, CD14 [36]. Binding with receptors, especially TLR4, causes phosphorylation and induces nuclear factor kappa-light-chain-enhancer of activated $\mathrm{B}$ cell $(\mathrm{NF}-\mathrm{kB})$ inflammatory signaling pathway [37]. In this study, we figured out that ACE exhibited antiinflammatory effect in LPS-treated macrophages through NF- $\mathrm{kB}$ signaling pathway.

Macrophages participate in immune responses which are accompanied by increased level of inflammatory mediators [38]. We compared the action of ACE on the yield of inflammatory mediators in homogenous population of peritoneal macrophages and in murine cell line. ACE suppressed the production of both NO (Fig. 1a, Fig. 4 a) and $\mathrm{PGE}_{2}$ (Fig. 1 c, Fig. 4 b). Although $\mathrm{NO}$ has a critical character in various body functions, its exceeding production in macrophages causes inflammation, cytotoxicity, or autoimmune disorders [39]. The efficacy of ACE on the expression level of iNOS, one of the key enzymes promoting the production of NO from arginine as response to different inflammatory stimuli [40], was examined (Fig. 1b). Another important mediator, $\mathrm{PGE}_{2}$, is made by the inducible enzyme COX-2 and it is related to the events constituting diverse chronic inflammatory diseases [41]. COX-2 produces PGs which causes inflammatory symptoms [42]. The restrained expression of COX-2 by ACE is shown in Fig. 1d. We found that ACE decreased the protein expression of pro-inflammatory mediators, $\mathrm{NO}$ and $\mathrm{PGE}_{2}$, as well as their inducible enzymes, iNOS and COX-2. LPS-stimulated macrophages and their production are considered as inflammatory mediators. They induce other pro-inflammatory cytokines namely TNF- $\alpha$ and IL- 6 which have been linked to the process in the chronic inflammatory diseases [43]. Both TNF- $\alpha$ and IL- 6 are the central mediators of sepsis, which is uncontrolled inflammatory response which can result in multi-organ failure and even demise [44]. In this study, the actions of ACE on the levels of the proinflammatory cytokines were examined (Fig. 2).

The LPS-leading signaling cascade induces the activation of NF- $\mathrm{kB}$ signaling pathways in either myeloid differentiation factor 88 (MyD88)-dependent or MyD88independent manner $[6,45]$. NF- $\mathrm{kB}$ transcription factors 


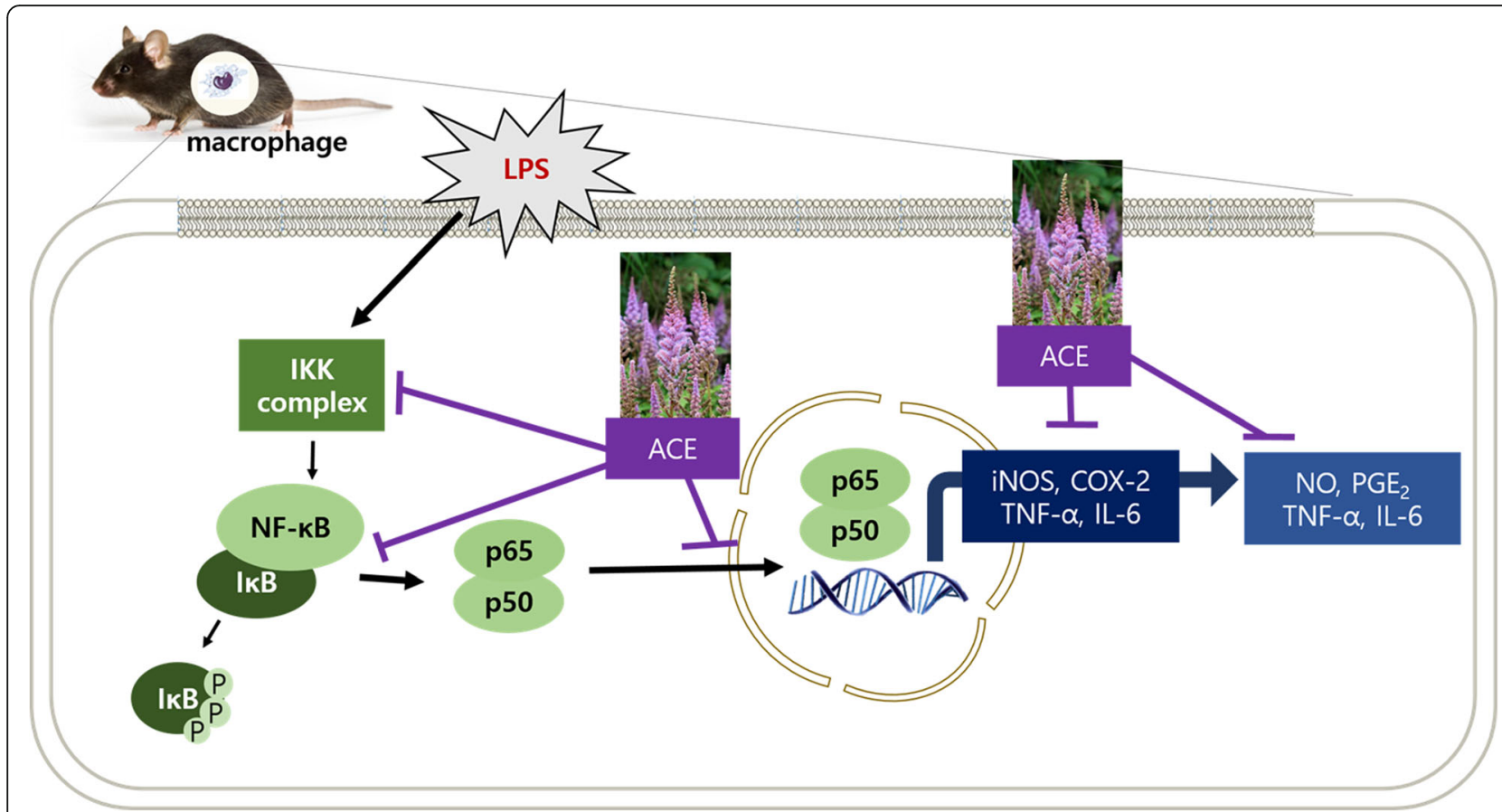

Fig. 5 The mechanism of ACE on inflammation in murine macrophages

are crucial for inflammation and important immuneregulatory genes $[28,46]$. In regards to physiological conditions, NF- $\mathrm{kB}$ is segregated in the cytoplasm which is by binding to inhibitory proteins such as IkBs. However, stimuli trigger the formation of IKK complexes comprising IKK $\alpha$, IKK $\beta$, and NF- $\mathrm{KB}$ essential modulator which is also known as IKK $\gamma$ [27]. The activated cells result in the phosphorylation and proteasome-mediated diminish in the level of IкB [47]. The sequence free NF$\kappa \mathrm{B}$ translocates into the nucleus, links to its accord sequence, and activates the target genes to do transcription [26]. The results of protein expression and immunofluorescence staining assays showed an increase in NF- $\mathrm{kB}$ p65 translocation into the nucleus (Fig. 3a, d). ACE inhibited the NF- $\mathrm{kB}$-mediated translocation of p65 and phosphorylation of IKB and IKK $\alpha / \beta$ in a dosedependent manner (Fig. 3b, c). These scrutinies suggest that ACE suppressed the initiation in the intracellular signaling cascades inhibiting the phosphorylation of IKK $\alpha / \beta$. Consequently, it had suppressive effect on the output of pro-inflammatory mediators through blocking NF-kB-mediated p65 translocation (Fig. 5).

\section{Conclusion}

In conclusion, this study demonstrated the antiinflammatory effect of ACE in LPS-stimulated macrophages. ACE suppressed the yield of pro-inflammatory cytokines mediators in murine macrophage cell line, RAW 264.7 cells. It conducted via the regulation on the NF- $\mathrm{kB}$ signaling pathway, especially through the translocation of p65 and the activation of ІкB. To confirm the effect of ACE on the output of inflammatory mediators for instance $\mathrm{NO}$ and $\mathrm{PGE}_{2}$, we evaluated their production in vitro as well as ex vivo with primary peritoneal macrophages. The findings indicate the effectiveness of ACE on LPS-induced inflammatory response in macrophages.

\section{Abbreviations}

ACE: A.chinensis ethanol extract; TG: Lipopolysaccharidethioglycollate; NF$\mathrm{kB}$ : Nuclear factor $\mathrm{kB}$; NO: Nitric oxide; $\mathrm{PGE}_{2}$ : Prostaglandin E2; iNOS: Inducible nitric oxide synthase; COX-2: Cyclooxygenase-2; (IL)6: Interleukin; TNF-a: tumor necrosis factor-alpha; IKK: IKB kinase; IKB: Inhibitor of $\mathrm{kB}$

Acknowledgements

Not applicable.

Authors' contributions

T.Y.G., B.R.J., and H.J.A. conceived and designed the experiments. T.Y.G. and B.R.J. performed the experiments. T.Y.G. and H.J.A. analyzed the data. C.H.H. and J.H.P. contributed reagents, materials, and analysis tools and involved in revisiting it critically for crucial intellectual contents. T.Y.G. and H.J.A. wrote the paper. The authors read and approved the final manuscript.

\section{Funding}

This research was supported by Basic Science Research Program of the National Research Foundation of Korea (NRF) (Grand number: NRF2018R1D1A1B07044794). As a chief of this research, C.H.H. contributed reagents, materials, and analysis tools and involved in informative contents.

Availability of data and materials

The datasets used and/or analyzed during the current study are available from the corresponding author on reasonable request. 


\section{Ethics approval and consent to participate}

The guidelines were adopted and promulgated by Sangji University according to the requirements demonstrated by the National Institutes of Health. All the experimental protocols were approved based on the Institutional Animal Care and Use Committee (IACUC) of Sangji University before the beginning of the study (IACUC Animal approval protocol No.2018-3).

\section{Consent for publication}

Not applicable.

\section{Competing interests}

No potential competing interests was reported by the authors.

\section{Author details}

'Department of Pharmacology, College of Korean Medicine, Sangji University, 83, Sangjidae-gil, Wonju-si, Gangwon-do 26339, Republic of Korea. ${ }^{2}$ Department of Korean Medicine Ophthalmology \& Otolaryngology \& Dermatology, College of Korean Medicine, Sangji University, 83, Sangjidae-gil, Wonju-si, Gangwon-do 26339, Republic of Korea. ${ }^{3}$ Hallym University, Chuncheon, Republic of Korea.

\section{Received: 30 April 2020 Accepted: 7 September 2020}

Published online: 07 October 2020

\section{References}

1. Heo S-J, Jang J, Ye B-R, Kim M-S, Yoon W-J, Oh C, et al. Chromene suppresses the activation of inflammatory mediators in lipopolysaccharidestimulated RAW 264.7 cells. Food Chem Toxicol. 2014;67:169-75.

2. Laskin DL, Laskin JD. Role of macrophages and inflammatory mediators in chemically induced toxicity. Toxicology. 2001;160(1-3):111-8.

3. Kanno S-i, Shouji A, Tomizawa A, Hiura T, Osanai Y, Ujibe M, et al. Inhibitory effect of naringin on lipopolysaccharide (LPS)-induced endotoxin shock in mice and nitric oxide production in RAW 264.7 macrophages. Life Sci. 2006; 78(7):673-81.

4. Rietschel ET, Kirikae T, Schade FU, Mamat U, Schmidt G, Loppnow H, et al. Bacterial endotoxin: molecular relationships of structure to activity and function. FASEB J. 1994;8(2):217-25.

5. Anwar MA, Basith S, Choi S. Negative regulatory approaches to the attenuation of toll-like receptor signaling. Exp Mol Med. 2013;45:e11.

6. Hattori Y, Hattori S, Kasai K. Lipopolysaccharide activates Akt in vascular smooth muscle cells resulting in induction of inducible nitric oxide synthase through nuclear factor-kappa B activation. Eur J Pharmacol. 2003;481(2-3):153-8.

7. Shih $\mathrm{RH}$, Wang CY, Yang CM. NF-kappaB signaling pathways in neurological inflammation: a mini review. Front Mol Neurosci. 2015;8:77.

8. Denkers EY, Butcher BA, Del Rio L, Kim L. Manipulation of mitogen-activated protein kinase/nuclear factor-kappaB-signaling cascades during intracellular toxoplasma gondii infection. Immunol Rev. 2004;201:191-205.

9. $\mathrm{Na}$ M, Min BS, An RB, Jin W, Kim YH, Song KS, et al. Effect of the rhizomes of Astilbe chinensis on UVB-induced inflammatory response. Phytotherapy Res. 2004;18(12):1000-4.

10. Xue $Y, X u X M$, Yan JF, Deng WL, Liao X. Chemical constituents from Astilbe chinensis. J Asian Nat Prod Res. 2011;13(2):188-91.

11. Zhang XH, Wang Z, Kang BG, Hwang SH, Lee JY, Lim SS, et al. Antiobesity effect of Astilbe chinensis Franch. Et Savet. Extract through regulation of Adipogenesis and AMP-activated protein kinase pathways in 3T3-L1 adipocyte and high-fat diet-induced C57BL/6N obese mice. Evid-Based Complemen Alternative Med. 2018;2018:1347612.

12. Jeon $B R$, Irfan $M$, Lee $S E$, Lee $J H$, Rhee $M H$. Astilbe chinensis modulates platelet function via impaired MAPK and PLCgamma2 expression. EvidBased Complemen Alternative Med. 2018;2018:3835021.

13. Sancheti S, Sancheti S, Lee SH, Lee JE, Seo SY. Screening of Korean medicinal plant extracts for alpha-Glucosidase inhibitory activities. Iranian J Pharmaceutical Res. 2011;10(2):261-4.

14. Yuk JE, Lee MY, Kwon OK, Cai XF, Jang HY, Oh SR, et al. Effects of astilbic acid on airway hyperresponsiveness and inflammation in a mouse model of allergic asthma. Int Immunopharmacol. 2011;11(2):266-73.

15. Chen F, Zhu X, Sun Z, Ma Y. Astilbin Inhibits High Glucose-Induced Inflammation and Extracellular Matrix Accumulation by Suppressing the
TLR4/MyD88/NF-kB Pathway in Rat Glomerular Mesangial Cells. Front Pharmacol. 2018;9:1187. PMID: 30459606.

16. Chen WD, Nie MH. [HPLC determination of bergenin in Astilbe chinensis (Maxim.) Franch. et Sav. and Bergenia purpurascens (Hook. F. et Thoms.) Engl]. Yao Xue Xue Bao. 1988;23(8):606-9. Chinese. PMID: 3254041.

17. Moon TC, Lin CX, Lee JS, Kim DS, Bae K, Son KH, et al. Antiinflammatory activity of astilbic acid from Astilbe chinensis. Biol Pharm Bull. 2005;28(1):24-6.

18. An HJ, Lee GG, Lee KT. Drynariae rhizoma increases immune response in mice. Nat Prod Commun. 2012;7(7):905-8.

19. Pavlou S, Wang L, Xu H, Chen M. Higher phagocytic activity of thioglycollate-elicited peritoneal macrophages is related to metabolic status of the cells. J Inflamm. 2017;14:4.

20. Muniandy K, Gothai S, Badran KMH, Suresh Kumar S, Esa NM, Arulselvan P. Suppression of Proinflammatory cytokines and mediators in LPS-induced RAW 264.7 macrophages by stem extract of Alternanthera sessilis via the inhibition of the NF-kappaB pathway. J Immunol Res. 2018;2018:3430684.

21. Li RJ, Gao CY, Guo C, Zhou MM, Luo J, Kong LY. The anti-inflammatory activities of two major Withanolides from Physalis minima via acting on NFkappaB, STAT3, and HO-1 in LPS-stimulated RAW264.7 cells. Inflammation. 2017;40(2):401-13.

22. Pipili-Synetos E, Kritikou S, Papadimitriou E, Athanassiadou A, Flordellis C, Maragoudakis ME. Nitric oxide synthase expression, enzyme activity and NO production during angiogenesis in the chick chorioallantoic membrane. $\mathrm{Br} \mathrm{J}$ Pharmacol. 2000;129(1):207-13.

23. Kawahara K, Hohjoh H, Inazumi T, Tsuchiya S, Sugimoto Y. Prostaglandin E2induced inflammation: relevance of prostaglandin E receptors. Biochim Biophys Acta. 2015;1851(4):414-21.

24. Adelizzi RA. COX-1 and COX-2 in health and disease. J Am Osteopath Assoc. 1999:99(11 Suppl):S7-12.

25. Feldmann M, Brennan FM, Maini RN. Role of cytokines in rheumatoid arthritis. Annu Rev Immunol. 1996;14:397-440.

26. Barnes PJ, Karin M. Nuclear factor-kappaB: a pivotal transcription factor in chronic inflammatory diseases. N Engl J Med. 1997;336(15):1066-71.

27. Yamaoka S, Courtois G, Bessia C, Whiteside ST, Weil R, Agou F, et al. Complementation cloning of NEMO, a component of the IkappaB kinase complex essential for NF-kappaB activation. Cell. 1998;93(7):1231-40.

28. Bonizzi G, Karin M. The two NF-kappaB activation pathways and their role in innate and adaptive immunity. Trends Immunol. 2004;25(6):280-8.

29. Mariathasan S, Monack DM. Inflammasome adaptors and sensors: intracellular regulators of infection and inflammation. Nat Rev Immunol. 2007;7(1):31-40

30. Du L, Li J, Zhang X, Wang L, Zhang W, Yang M, et al. Pomegranate peel polyphenols inhibits inflammation in LPS-induced RAW264.7 macrophages via the suppression of TLR4/NF-kappaB pathway activation. Food Nutr Res. 2019;63:3392. https:/foodandnutritionresearch.net/index.php/fnr/article/view/3392/9217.

31. Kang J, Zhang Y, Cao X, Fan J, Li G, Wang Q, et al. Lycorine inhibits lipopolysaccharide-induced iNOS and COX-2 up-regulation in RAW264.7 cells through suppressing P38 and STATs activation and increases the survival rate of mice after LPS challenge. Int Immunopharmacol. 2012;12(1): 249-56

32. Lu CL, Zhu YF, Hu MM, Wang DM, Xu XJ, Lu CJ, et al. Optimization of astilbin extraction from the rhizome of Smilax glabra, and evaluation of its anti-inflammatory effect and probable underlying mechanism in lipopolysaccharide-induced RAW264.7 macrophages. Molecules. 2015;20(1): 625-44.

33. Rao K, Roome T, Aziz S, Razzak A, Abbas G, Imran M, et al. Bergenin loaded gum xanthan stabilized silver nanoparticles suppress synovial inflammation through modulation of the immune response and oxidative stress in adjuvant induced arthritic rats. J Mater Chem B. 2018;6(27):4486-501.

34. Zhang X, Goncalves R, Mosser DM: The isolation and characterization of murine macrophages. Curr Protoc Immunol 2008, Chapter 14:Unit 1411.

35. Kim KN, Heo SJ, Yoon WJ, Kang SM, Ahn G, Yi TH, et al. Fucoxanthin inhibits the inflammatory response by suppressing the activation of NF-kappaB and MAPKs in lipopolysaccharide-induced RAW 264.7 macrophages. Eur J Pharmacol. 2010;649(1-3):369-75.

36. Limtrakul P, Yodkeeree S, Pitchakarn P, Punfa W. Suppression of inflammatory responses by black Rice extract in RAW 264.7 macrophage cells via Downregulation of NF-kB and AP-1 signaling pathways. Asian Pac J Cancer Prev. 2015;16(10):4277-83.

37. Tan WS, Arulselvan P, Karthivashan G, Fakurazi S. Moringa oleifera flower extract suppresses the activation of inflammatory mediators in 
lipopolysaccharide-stimulated RAW 264.7 macrophages via NF-kappaB pathway. Mediators Inflamm. 2015;2015:720171.

38. Foster JR. The functions of cytokines and their uses in toxicology. Int J Exp Pathol. 2001;82(3):171-92.

39. Dandona P, Chaudhuri A, Dhindsa S. Proinflammatory and prothrombotic effects of hypoglycemia. Diabetes Care. 2010;33(7):1686-7.

40. Forstermann U, Sessa WC. Nitric oxide synthases: regulation and function. Eur Heart J. 2012;33(7):829-37 837a-837d.

41. Ricciotti E, FitzGerald GA. Prostaglandins and inflammation. Arterioscler Thromb Vasc Biol. 2011;31(5):986-1000.

42. Lee HJ, Shin JS, Lee WS, Shim HY, Park JM, Jang DS, et al. Chikusetsusaponin IVa methyl Ester isolated from the roots of Achyranthes japonica suppresses LPS-induced iNOS, TNF-alpha, IL-6, and IL-1 beta expression by NF-kappaB and AP-1 inactivation. Biol Pharm Bull. 2016;39(5):657-64.

43. Brennan FM, Mclnnes IB. Evidence that cytokines play a role in rheumatoid arthritis. J Clin Invest. 2008;118(11):3537-45.

44. Qin X, Jiang X, Jiang X, Wang Y, Miao Z, He W, et al. Micheliolide inhibits LPS-induced inflammatory response and protects mice from LPS challenge. Sci Rep. 2016;6:23240.

45. Chan ED, Riches DW. IFN-gamma + LPS induction of INOS is modulated by ERK, JNK/SAPK, and p38(mapk) in a mouse macrophage cell line. Am J Physiol Cell Physiol. 2001;280(3):C441-50.

46. Karin M, Ben-Neriah Y. Phosphorylation meets ubiquitination: the control of NF-[kappa] B activity. Annu Rev Immunol. 2000;18:621-63.

47. Zandi E, Rothwarf DM, Delhase M, Hayakawa M, Karin M. The IkappaB kinase complex (IKK) contains two kinase subunits, IKKalpha and IKKbeta, necessary for IkappaB phosphorylation and NF-kappaB activation. Cell. 1997;91 (2):243-52.

\section{Publisher's Note}

Springer Nature remains neutral with regard to jurisdictional claims in published maps and institutional affiliations.

Ready to submit your research? Choose BMC and benefit from:

- fast, convenient online submission

- thorough peer review by experienced researchers in your field

- rapid publication on acceptance

- support for research data, including large and complex data types

- gold Open Access which fosters wider collaboration and increased citations

- maximum visibility for your research: over $100 \mathrm{M}$ website views per year

At $\mathrm{BMC}$, research is always in progress.

Learn more biomedcentral.com/submissions 